\section{PREVALENCE OF HEMOGLOBINOPATHIES IN THE POPULATION OF DIBRUGARH AND IT'S ASSOCIATION WITH SEX}

KEY WORDS:

haemoglobin, haemoglobi nopathies

\section{Dr.Ābanti Bora Baruah}

\section{Dr Rwitusmita Bharali*}

Associate professor of physiology,assam medical college,dibrugarh Demonstrator Department Of Physiology Assam medical College,Dibrugarh

Demonstrator of physiology, assam medical college, dibrugarh Demonstrator Department Of Physiology Assam medical College,Dibrugarh *Corresponding Author

Introduction- Haemoglobinopathies are one of the commonest hereditary disorders in south-east asia and pose a major health problem.The data of their prevalence in the society may help in the future prevention of heath hazards.Materials and method:-Agarose gel electrophoresis was used to study the haemoglobin typing in 118 individuals.The Hb percentage was studied by cyanmethhaemoglobin method.Result:-It was observed that prevalence of abnormal Hb was common in females as compared to males.And moreover in each type of $\mathrm{Hb}$, the percentage of $\mathrm{Hb}$ was more in males as compared to females.Conclusion:-Prevalance of abnormal $\mathrm{Hb}$ is common in dibrugarh,Their early detection can help in preventing serious health hazards.

\section{INTRODUCTION:}

Hemoglobinopathies are the inherited disorders of haemoglobin which are the most studied pathologies. These genetic disorders are considered a very important health care threat in many tropical countries. l. These diseases cause major heath burden in south east asian ,particularly in India. These disorders are caused by genetic mutation in the globin gene sequence, resulting in a spectrum of clinical manifestations ranging from asymptomatic career state to major disease, requiring repeated blood transfusions and associated increased morbidity and mortality. The prevention of these disorders lies in effective screening of at-risk population, namely premarital men and women and anti-natal women. Various studies have been done in the past which have showed different prevalence patterns of these diseases in different parts of the country.,2,3,4.Therefore this study was undertaken to study the prevalence of abnormal haemoglobin in the population of dibrugarh and its relation with sex of the individual.

\section{Materials and Methods:-}

In this cross sectional study 118 young individuals in the age group of 9-19 years were selected from the general population of Dibrugarh randomly.The ethical committee clearance and an informed consent of the subjects were taken. Subjects with a history of blood transfusion within last four months and age group outside the defined age range were excluded.The study was conducted in the department of Physiology,Assam Medical College,Dibrugarh.

$4 \mathrm{ml}$ of venous blood were collected in the EDTA vacutainer from each subject. The hemosylate is prepared fresh on the same day the electrophoresis is performed. The sample is prepared by washing the red blood cells lysing the cells and pipetting the hemosylate. The hemosylate is made to run on Agarose gel electrophoresis.Hb S was confirmed by sickling test using $2 \%$ sodium metabisulphite.The foetal haemoglobin was estimated by alkalidenaturation technique.The total haemoglobin in blood was estimate by cyanmethaemoglobin method.

Statistical analysis of data was carried out using SPSS Versionl6. Data were presented in the forms of mean \pm standard deviation and Statistical signi cance was ascertained-by unpaired Ttest.

\section{Result and Observation:-}

The relative pevalance of different hemoglobinopathies is the study population is shown in table l.The distribution of haemoglobin types in relation to sex is shown in Table 2 ,It is seen that percentage of $\mathrm{HbA} / \mathrm{A}$ in males is more than females. Whereas the percentage of $\mathrm{HbA} / \mathrm{E}, \mathrm{HbE} / \mathrm{E}, \mathrm{HbE} / \mathrm{F}$, $\mathrm{Hb} \mathrm{A} / \mathrm{S}$ and $\mathrm{HbS} / \mathrm{S}$ in more in female than in male.Table 3 shows the mean \pm SD levels of haemoglobin in different haemoglobin types with respect to sex.It is seen that haemoglobin level is more in males as compared to females in $\mathrm{HbA} / \mathrm{A}$ and $\mathrm{HbE} / \mathrm{E}$ which was statistically highly significant. For the type $\mathrm{HbE} / \mathrm{E}$ although $\mathrm{Hb}$ level is more in males as compared to females but the increase was not statistically significant.Comparision was not done for $\mathrm{Hb} \mathrm{A} / \mathrm{S}, \mathrm{Hb} \mathrm{S} / \mathrm{S}$ and $\mathrm{Hb} \mathrm{E} / \mathrm{F}$ as the number of cases were very less.

Table 1:-Relative prevalence of different hemoglobinopathies is the study population

\begin{tabular}{|c|c|c|c|c|c|c|c|}
\hline $\begin{array}{c}\text { Types of } \\
\text { haemoglo } \\
\text { bin }\end{array}$ & $\mathrm{HbA} / \mathrm{HbA} / \mathrm{HbE} / \mathrm{HbA} / \mathrm{H}$ & $\mathrm{HbS} / \mathrm{S}$ & $\mathrm{HbE} / \mathrm{F}$ & total \\
\hline $\begin{array}{c}\text { No of } \\
\text { Cases }\end{array}$ & 81 & 24 & 8 & 2 & 2 & 1 & 118 \\
\hline$\%$ of cases & 68.64 & 20.33 & 6.78 & 1.69 & 1.69 & 0.85 & 100 \\
\hline
\end{tabular}

Table 2:- The distribution of haemoglobin types in relation to sex

\begin{tabular}{|c|c|c|c|c|c|c|c|}
\hline Sex & total & $\mathrm{HbA} / \mathrm{A}$ & $\mathrm{HbA} / \mathrm{E}$ & $\mathrm{HbE} / \mathrm{E}$ & $\mathrm{HbA} / \mathrm{S}$ & $\mathrm{HbS} / \mathrm{S}$ & $\mathrm{HbE} / \mathrm{F}$ \\
\hline \multirow{3}{*}{ Male } & 65 & 49 & 11 & 3 & - & 1 & 1 \\
\cline { 2 - 8 } & $100 \%$ & $75.38 \%$ & $16.92 \%$ & $4.62 \%$ & - & $1.54 \%$ & $1.54 \%$ \\
\hline \multirow{2}{*}{ Female } & 53 & 32 & 13 & 5 & 1 & 1 & 1 \\
\cline { 2 - 8 } & $100 \%$ & $60.38 \%$ & $24.53 \%$ & $9.43 \%$ & $1.89 \%$ & $1.89 \%$ & $1.89 \%$ \\
\hline
\end{tabular}

Table3:- Shows the mean \pm SD level of haemoglobin in different haemoglobin types with respect to sex

\begin{tabular}{|c|c|c|c|}
\hline $\begin{array}{c}\text { Type of } \\
\text { haemoglobin }\end{array}$ & $\begin{array}{c}\mathrm{HbA} / \mathrm{A} \\
\text { mean } \pm \mathrm{SD}\end{array}$ & $\begin{array}{c}\mathrm{HbA} / \mathrm{E} \\
\text { mean } \pm \mathrm{SD}\end{array}$ & $\begin{array}{c}\mathrm{HbE} / \mathrm{E} \\
\text { mean } \pm \mathrm{SD}\end{array}$ \\
\hline male & $14.2 \pm 0.82$ & $9.7 \pm 0.2$ & $8.1 \pm 1.6$ \\
\hline female & $11 \pm 1.1$ & $8.6 \pm 0.23$ & $6.3 \pm 1.15$ \\
\hline
\end{tabular}

Table 4:-showing the comparision between different types of haemoglobin in relation to sex

\begin{tabular}{|l|c|}
\hline \multicolumn{1}{|c|}{ categories } & significance \\
\hline male $\mathrm{HbA} / \mathrm{A}$ & $\mathrm{HS}$ \\
vs & \\
female $\mathrm{HbA} / \mathrm{A}$ & \\
\hline male $\mathrm{HbA} / \mathrm{E}$ & $\mathrm{HS}$ \\
vs & \\
female $\mathrm{HbA} / \mathrm{E}$ & \\
\hline male $\mathrm{HbE} / \mathrm{E}$ & $\mathrm{NS}$ \\
vs & \\
female $\mathrm{HbE} / \mathrm{E}$ & \\
\hline
\end{tabular}


$\{$ p value $>0.05$ was non-signi cant $(\mathrm{NS}) ; \mathrm{p}$ value $<0.05$ was as signi $\operatorname{cant}(\mathrm{S}) ; \mathrm{p}$ value $<0.01$ was highly signi cant $(\mathrm{HS}) ; \mathrm{p}$ value $<0.001$ was very highly signi $\operatorname{cant}(\mathrm{VHS})\}$

\section{DISCUSSION:-}

Hemoglobinopathies are a growing global public health problem with an estimated 9,00,000 births of clinically signi cant thalassemia disorders expected to occur in the next 20 years.5.The present study shows a high prevalence of haemoglobinopathies in females as compared to males.The present study showed that the prevalence of $\mathrm{Hb} \mathrm{A} / \mathrm{E}$ is $20 \%$. And the prevalence of $\mathrm{Hb} \mathrm{E} / \mathrm{E}$ is $6.7 \%$..This finding is inconsistent with the findings of Beutler E et al 6 and Flatz $\mathrm{G} 7$. Studies have shown that there is very high incidence of haemoglobinopathies in paediatric age group (0-18 years) as $55.7 \% .8 \mathrm{This}$ is very well correlated with our study. $\mathrm{HbE}$ is the most popular haemoglobin variant in Southeast Asia as well as in Northeast India. High prevalence of haemoglobin E $(>50 \%$ ) were observed among the Soui, Thai Khmer, So, Yor and Puthai populations inhabiting the region near Cambodia and Laos, higher frequency of $\mathrm{HbE}$ in the Phayeng (a Chakpa) of Manipur can be taken as a favour on the hypothesis of association of Austroasiatic race and HbE.9

\section{CONCLUSION:-}

The frequency of hemoglobinopathy is increased by consanguity \& endogenous mating and the tribal community in India are facing the problem at large scale.Therefore early screening for haemoglobinopathies and counselling will lead to a decrease in this serious group of diseases and reduce the burden of the future generation.

\section{REFERENCES:-}

1. Angastiniotis M, Modell B. Global epidemiology of hemoglobin disorders. Annals of the New York Academy of Sciences 1998;850:251-269

2. Madan N, Sharma S, Sood SK, Colah R, Bhatia LH. Frequency of betathalassemia trait and other hemoglobinopathies in northern and western India. Indian J Hum Genet. 2010;16:16-25.

3. Sachdev R, Dam AR, Tyagi G. Detection of $\mathrm{Hb}$ variants and hemoglobinopathies in Indian population using HPLC: report of 2600 cases. Indian J Pathol Microbiol. 2010;53:57-62.

4. Priyaranjan Chattopadhyay, Soumya Kundu, Tarak Nath Saha, Kausik Chatterjee. Study of hemoglobinopathies at a referral laboratory in a western district of West Bengal among the antenatal women and premarital men and women: a 2 years study. International Journal of Contemporary Medical Research 2019;6(6):F24-F27.

5. Vichinsky EP. Changing patterns of thalassemia worldwide. Ann NY Acad Sci 2005;1054:18-24

6. Beutler E. The sickle cell diseases and related disorders. In: Beutler E MD, Lichtman MA MD, Coller BS MD, Kipps TJ MD PhD, Seligsohn U MD, editors. Williams hematology. 6th ed. McGraw-Hill Professional; November 28, 2000. p581-606. [6]

7. Flatz G. Hemoglobin E:Distribution and population dynamics. Humangenetik 1967;3:189

8. Sengupta M. Thalassaemia among the tribal Communities of India. The Internet Journal of biological Anthropology 2008; 1(2):e.DOI: 10.5580/9a l

9. Karthika Ml*, Ksh Gomti Devi2, Deisha B Rymbuil, Prakash Bhardwaj 1, Senti Aol, Sumit Kumar 1:Prevalence of Hemoglobinopathies in Manipur; Journal of Dental and Medical Sciences, . Volume 14, Issue 8Ver. IV (Aug. 2015), PP 17-20 